The Japanese Journal of Animal Psychology 40-2, 29-36 (1990)

$\overline{\text { 研 究 }}$

\author{
ラットを用いた新しい持続痛測定法 \\ 一ホルマリン誘発性後肢屈曲反応を指標として一
}

上智大学山崎 重 明
酒 开不夫
山 中 祥 男

\title{
A New Rat Model for Tonic Pain Using Formalin- induced Hind Paw Flexion Responses
}

\author{
Shigeaki Yamazaki, Mikio Sakai and Yoshio Yamanaka \\ Sophia University
}

\begin{abstract}
It is abunduntly clear that there are major differences between acute and chronic pain. However, many animal studies for pain and nociception employ short-lasting noxious stimuli which may have limited relevance to prolonged or chronic pain states.

In this study, we provide a new rat tonic pain model developed in our laboratory which is characterized by recording rats hind paw flexion responses with the passage of time after dilute formalin injection. The response burst, 15 responses and more per minute, were constantly induced for at least 45 minutes, i. e., from 25 to 70 minutes after formalin injection, and were considered to be due to tonic nociception of the animal because of their high sensitivity to morphine.

A few animals showed poor responses (5 responses or less per minute) consistently. The inhibition of formalin-induced flexion responses observed in these animals was estimated to be mediated by endogenous opioid systems, for those inhibitions were antagonized by naloxone, an opioid antagonist.
\end{abstract}

痛みのメカニズムを理解するため，あるいは 有効な除痛法を開発するためには，動物を用い た痛みテストが不可欠である。

これまでにも数多くのテストが考案され，痛 みの実験モデルとして，あるいは鎮痛活性評価 法として広く使用されているが，そのほとんど は痛み刺激として一過性ひ侵害刺激を採用して
いる。熱や圧, あるいは電気的刺激を動物が逃 避行動を示すまで（すなわち痛覚閾まで）呈示 するこれらの方法では, 痛みの受容はせいぜい 数秒以内である。

こうしたテストは, 急性痛のモデルとしては 十分にその役目を果たすが, 別の夕イプの痛み, すなわち組織損傷やその他の病理的原因に基づ 
山崎・酒井・山中：ラットを用いた新しい持続痛測定法

く，相対的に時間経過の長い痛み（持続痛）の 実験モデルとしては適切ではない。事実，急性 の痛み刺激を用いて評価された鎮痛薬の効果 は，臨床場面のそれと必ずしも一致しない。加 えて, 最近の多くは証拠は, 持続痛が急性痛の 時間的継続に起因するものではなく，両者はそ れぞれ別個の信号系により伝達され，その抑制 にはそれぞれに異なる鎮痛系が関与することを 示唆している (Dennis \& Melzack 1979)。

痛みの持つ多用な側面にアプローチするため には，急性痛モデルだけでは不十分であり，持 続的な侵害刺激を動物に呈示し，その反応を継 時的に評価する方法を開発することが必要であ る。

近年，いくつかの持続痛動物モデルが報告さ れ始めた（DeCastro-Costa et al. 1981, Sugimoto et al. 1986, Wall et al. 1979)。その 中でも Dubuisson \& Dennis（1977）によって 提唱された“formalin test”は，処置の簡便さと ともに, 組織損傷 (炎症) に起因する自発的痛 み反応を継時的に測定するという点において優 れた持続痛モデルであり，ラットやネコだけで なく, 最近では霊長類にも適用されている (Alreja et al. 1984)。しかしながら，複数（4 種類）の反応カテゴリーそれぞれの出現時間か ら痛み得点を算出するという従来の方法は, 行 動観察によって痛みの程度を評価するので, 判 定に際し主観の入り込む危険性があること, 注 入肢 (前肢) に対して動物が示す複雑な応変化 を正確に弁別することが極めて困難であること などの問題点がある。また，痛み得点の基にな る各反応カテゴリーについて個別にその出現時 間の変化をみると, 時間経過に伴って各反応の トポグラフィックな分布にかたよりが生じる (山中他 1981)。このことは, “formalin test” における痛み得点が, 必ずしも同質の痛み成分 を反映する指標ではないという可能性を示唆す る。反応カテゴリーのうちの一つだけを指標と する研究も行われてはいるが (Abbott et al. 1981, Sugimoto et al. 1986), これらの個々の
反応は集中的に出現する時間が短い。

我々は, ホルマリン注入後の行動変化を分析 する過程で, ラットの後肢皮下にホルマリンを 注入すると, 他の痛み反応に混入して注入肢の 小さな屈曲が高頻度で出現することを観察し た。

本研究は, これまで全く観察の対象外であっ たこの屈曲反応を指標としてホルマリン痛を客 観的に定量化し，ラットを対象とする持続痛測 定の一手段を提供するものである。

\section{方法}

被験体：体重 $280 \mathrm{~g}$ から $340 \mathrm{~g}$ までの雄性 ウィスター系アルビノラット（埼玉実験動物供 給所）を 32 匹使用した。動物は室温 $25^{\circ} \mathrm{C}, 12$ $\mathrm{hr} . / 12 \mathrm{hr}$.の明暗環境下 (明期 : 午前 8 時〜午後 8 時）で個別飼育され，餌・水ともに随時与えら れた。なお，馴化訓練およびテストは，各々， 明期の同一時間帯（午前 9 時〜午後 6 時）に施 行された。

馳化訓練：本研究では, ラットの後肢屈曲反 応を測定するため, 空中保定の手続を採用した。 同様の手続は他の痛みテストでも行われている が (Otsuki et al. 1986, 佐藤 1981), 空中保定 に限らず，一般に強制的な不動状態は動物に とって極めてストレスフルであり, 痛みの生理 的メカニズムに重大な影響を及ぼすとともに， 行動面では強い鎮痛効果（いわゆるストレス鎮 痛）を生じさせる（Porro \& Carli 1988)。しか しながら, 後肢屈曲反応を指標とする本法の場 合, 空中保定は, 他の痛み反応や動物の姿勢変 化に影響されることなく屈曲反応のみを誘発さ せ, 後述の方法により反応量を客観的かつ具体 的に記録することを可能にするという点におい て重要な手続である。

拘束ストレスの鎮痛作用は, 動物がその拘束 状態を繰り返し経験することにより徐々に減 弱, 消失する (Amir \& Amit 1979)。そこで今 回の実験テストでは, ラットを，テスト場面と ほぼ同様に頭部と四肢を出した状態で布製の拘 
束衣に包み，宙づりに 120 分間保定するセッ ションを連続 12 日間行い, テスト時の拘束状態 に対する馴化訓練とした。

テスト手続：12 日間の馴化訓練終了の翌日, 屈曲反応の測定を行った。被験体を 3 群に分け, 生理食塩水群 $(\mathrm{n}=9)$ に生理食塩水を，また $2 \%$ ホルマリン群 $(\mathrm{n}=11)$ および $4 \%$ ホルマリン群 $(\mathrm{n}=12)$ には生食ホルマリン（2\%または $4 \%$ Formaldehyde 溶液)を $40 \mu 1$ 注入した。注入に は $100 \mu$ 注射筒, $27 \mathrm{G}$ 注射針を用い, 可能な限 り速やかに注入した。なお, “formalin test“で は，5\%，50 $\mu 1$ のホルマリン溶液を使用してい るが, 本研究では, 屈曲反応を選択的に生じさ せ易い低濃度，低容量を使用した。ただし，そ れでもホルマリン注入直後は注入部位への licking 反応が鎮繁に生じ, これが屈曲反応測定 の妨げとなるため, 注入直後の 5 分間はラット をホームケージに戻した。

次に,馴化訓練と同様にラットを空中保定し, 注入肢の足首に約 $30 \mathrm{~cm}$ の糸を結びつけた。系 の先端は張力トランスデューサーに接続し, 注 入肢の上下動（屈曲反応）を電圧に変換, 増幅 してペンオシログラフに記録した。記録装置は 2 台を同時に使用し, このうち 1 台は紙送り速
度 $5 \mathrm{~cm} / \mathrm{min}$. として個別の波形の検証ならび に反応回数の計測に用い, 他の 1 台は $20 \mathrm{~cm} /$ $\mathrm{hr}$ ，で記録し，全反応パターンのモニターとし た。測定は, 注入後 10 分から 120 分まで行った。 なお，測定は各被験体につき 1 回を原則とし たが，例外的な反応パターンを示したラットに 対しては，更に 12 日間の馴化訓練を行った後, 反対側の後肢（前回の非注入肢）に前回と同濃 度のホルマリンを注入し, 再度測定した。また， 麻薬性鎖痛薬に対する屈曲反応の感受性を検討 するため, $4 \%$ ホルマリン群の 2 匹を同様の手続 で再テストし，モルヒネ (morphine hydrochloride) $1,5 \mathrm{mg} / \mathrm{kg}$ と，その特異的拮抗薬である ナロキソン (naloxone hydrochloride) $1 \mathrm{mg} / \mathrm{kg}$ を，注入後それぞれ 30 分と 50 分の時点で皮下 投与した。

\section{結果}

希釈ホルマリン溶液をラットの後肢背側皮下 に注入すると, その後肢に連続的な屈曲反応が 生じる。Fig.1 は, 生理食塩水と 4\%ホルマリン 溶液をそれぞれ $40 \mu 1$ 注入したときの注入肢の 動きをペンオシログラフ（紙送り速度 $5 \mathrm{~cm} /$ min.) に記録したものである。今回の実験では，
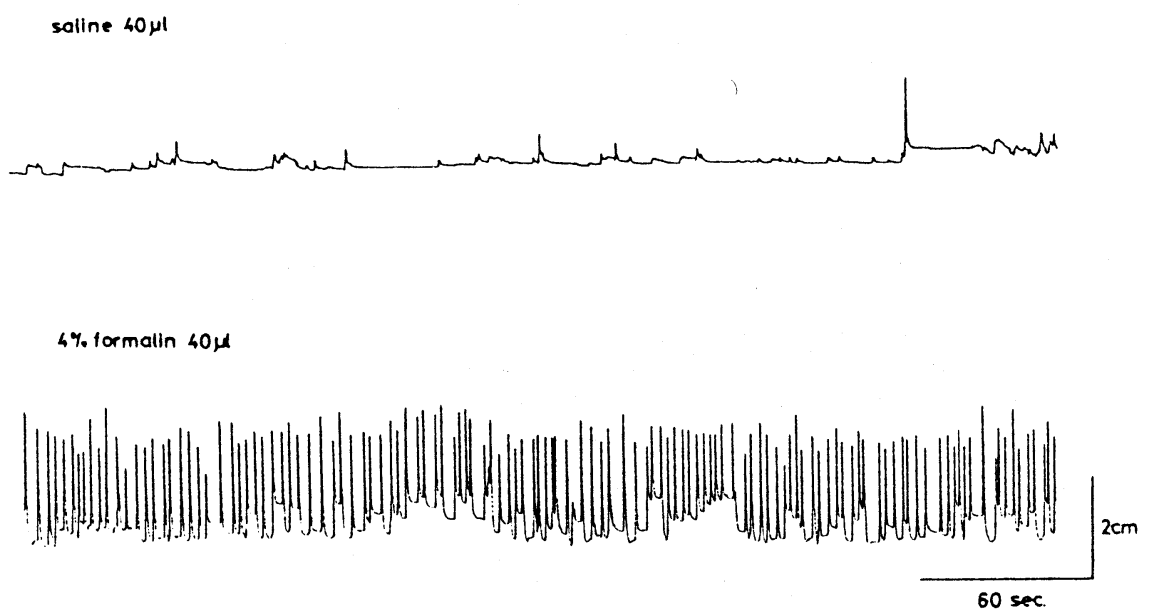

Fig. 1 Records of hind paw flexion responses induced by $40 \mu \mathrm{l}$ of saline (upper) and $40 \mu 1$ of $4 \%$ formalin (lower). 
山崎・酒井・山中：ラットを用いた新しい持続痛測定法

この記録をもとに 1 分間当たりの屈曲反応数を 計測し, 痛み強度の指標とした。ただし, 非注 入肢にも微細な上下動が生じるので, 立ち上が りが速く, $1 \mathrm{~cm}$ 以上の振幅が記録されたものを 屈曲反応とした。

Fig.2 は，ホルマリン溶液を注入されたラッ トの代表的な反応パターンの例であり，その全 体記録（紙送り速度 $20 \mathrm{~cm} / \mathrm{hr}$.) と，1 分間当た りの反応数を示した。この例では, ホルマリン 注入後 20 分から 75 分にかけて屈曲反応が高頻 度で出現し, その後急速に消失している。一般 的に, 反応増加の開始, 終了時は個体によりわ ずかに異なるが (前後 5 分から 10 分), ホルマ リン濃度に関係なく少なくとも 45 分間の反応 群発が観察された。この間の反応数は数分ごと に増減を繰り返すが，この傾向は $2 \%$ ホルマリ ン溶液注入群で更に顕著であった。

ホルマリン溶液を注入された被験体のうち, 3 匹は 1 分間当たりの反応数が常に 5 回以下 と,他のラットとは著しく異なるため, そのデー 夕は除外した $(2 \%-2$ 例， $4 \%-1$ 例)。これら の低反応ラットに対しては再テストを行った
が，1回目と同程度の反応が出現するのみで あった。しかしながら，このうち 2 匹 $(2 \%, 4 \%$ 各 1 例) にナロキソン $1 \mathrm{mg} / \mathrm{kg}$ を皮下投与した ところ, 約 30 分間にわたつて活発な屈曲反応が 観察された (Fig.3)。

Fig.4には, 生理食塩水, $2 \%, 4 \%$ ホルマリン 各群の, 1 分間当たりの平均反応数を示した。生 食群 $(\mathrm{n}=9)$ が全体を通じほとんど無反応（1 分間平均 1.1 回）なのに対し, ホルマリン群は 両群とも注入後 25 分から 70 分かけて高い反応 数を示したが,この間の平均反応数は $2 \%$ 群 $(\mathrm{n}=9)$ で 13.8，4\%群 $(\mathrm{n}=11)$ で 19.2 と, ホルマリン濃度間に有意な差がみられた $(t(18)=$ $10.14, p<.001) 。 70$ 分以降, 反応数は急速に減 少し, その平均反応数は $2 \%$ 群で $3.3,4 \%$ 群で 4.9 と接近した(ただし有意差あり, $t(18)=2.87$, $p<.0 .1$ )。

$4 \%$ ホルマリン群の 2 匹は, モルヒネの鎮痛効 果を検証するため再テストした。馴化訓練の後, 反対側後肢に $4 \%$ ホルマリンを注入し, 反応が 最も安定して出現する 30 分の時点でモルヒネ $1 \mathrm{mg} / \mathrm{kg}$ または $5 \mathrm{mg} / \mathrm{kg}$ を, さらにその 20 分

No. 810

$4 \%$ formalin $40 \mu$
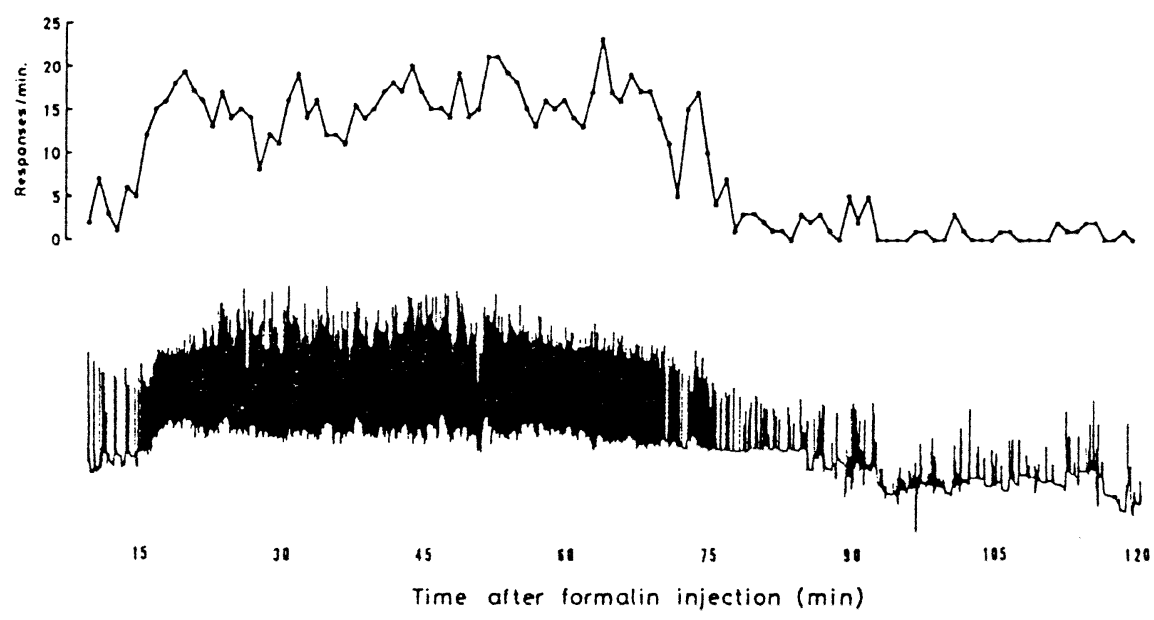

Fig. 2 Record of flexion responses by $40 \mu 1$ of $4 \%$ formalin (lowem) and response rate per minute (upper). 
No.708

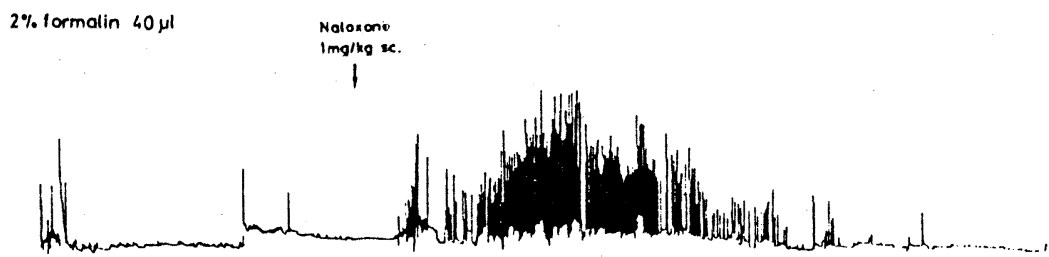

No. 805
$4 \%$ formalin $40 \%$ Naloxong
img/kg se.

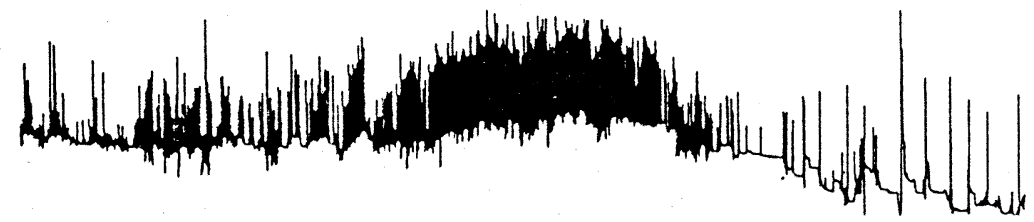

15

15

61

75

10

105

120

Time after formalin injection ( $\mathrm{min}$ )

Fig. 3 Records of flexion responses by $2 \%$ formalin (upper) and $4 \%$ formalin (lower). These rats showed poor responses constantly, but a phasic response burst was observed after naloxone administration.

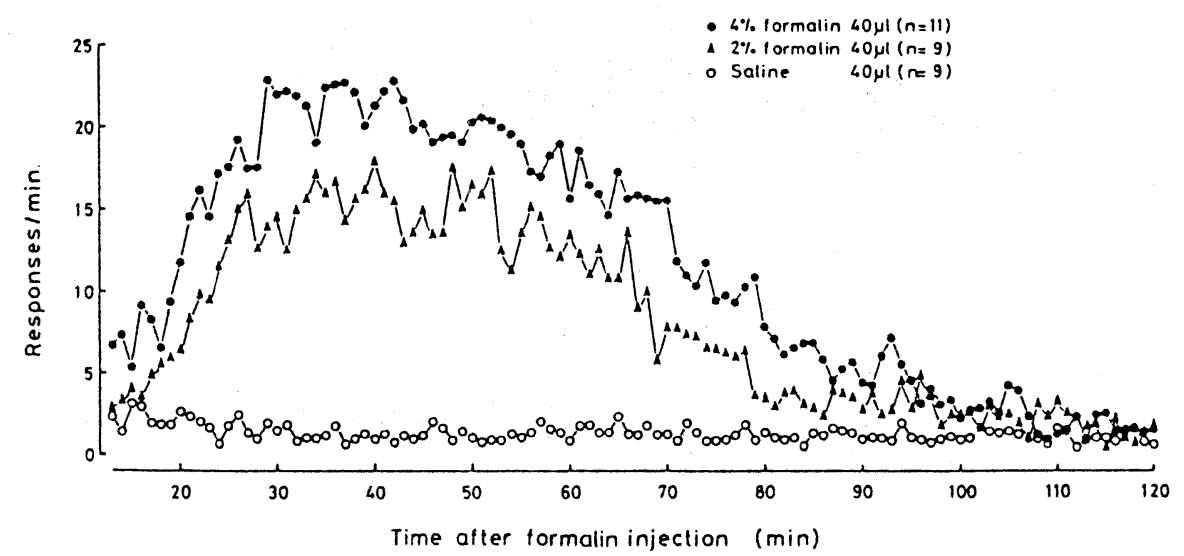

Fig. 4 Mean response rate per minute in each group. 
後にナロキソン $1 \mathrm{mg} / \mathrm{kg}$ を皮下投与した。モル 七ネ $1 \mathrm{mg} / \mathrm{kg}$ は, その投与から 5 分後以降の反 応数を $75 \%$ にまで抑制し，モルヒネ $5 \mathrm{mg} / \mathrm{kg}$ は完全な鎮痛効果をもたらした。また，これら のモルヒネの効果はナロキソンにより逆転さ れ，反応数はモルヒネ投与前のレベルまで速や かに回復した（Fig.5）。

\section{考 察}

侵害刺激からの逃避行動としての下肢屈曲反 応は, ヒトを含めた多くの動物にみられるが, そのほとんどは急性の刺激に対する一過性の春 髄反射である（Willer et al. 1979）。今回の実 験では, ラット後肢皮下へのホルマリン溶液注 入後, 屈曲反応の群発が一定時間観察された。 この反応は，麻薬性鎮痛薬によって抑制を受け ることから, 明らかに痛みに由来する反応と思 われるが，持続的かつ逃避不可能な刺激によつ て連続的に惹起されるという点において, 春髄 で媒介される他の一般的な屈曲反応とは異な
る。ホルマリン誘発性後肢屈曲反応は, ラット が痛みを一時的に軽減するために行う随意的な 対処行動であろうと推察される。

Dubuisson \& Dennis（1977）によれば, “formalin test”における痛み得点は 2 相性の継 時的変化を示す。すなわち注入直後約 5 分間の 第 1 期と, 約 20 分後以降の第 2 期とである。こ のうち前者は侵害受容器の直接的刺激による急 性痛を，後者は皮下組織の炎症に起因する持続 痛を反映すると考えられている (Sugimeto et al. 1986)。本研究では, ホルマリン注入後 25 分 から 70 分にかけて高頻度の屈曲反応が観察さ れたが，こちらは“formalin test”における第 2 期の痛み（持続痛）に対応する。ただし， “formalin test”における痛み得点が注入後約 30 分を頂点としてゆるやかな増加, 減少カーブ を描くのに対し, 屈曲反応数は比較的急速に増 加, 消失し, またその間若干の増減を繰り返す。 屈曲反応のこうした特徵は, 我々が日常経験す る持続的な痛みの特徵によく類似すると思われ

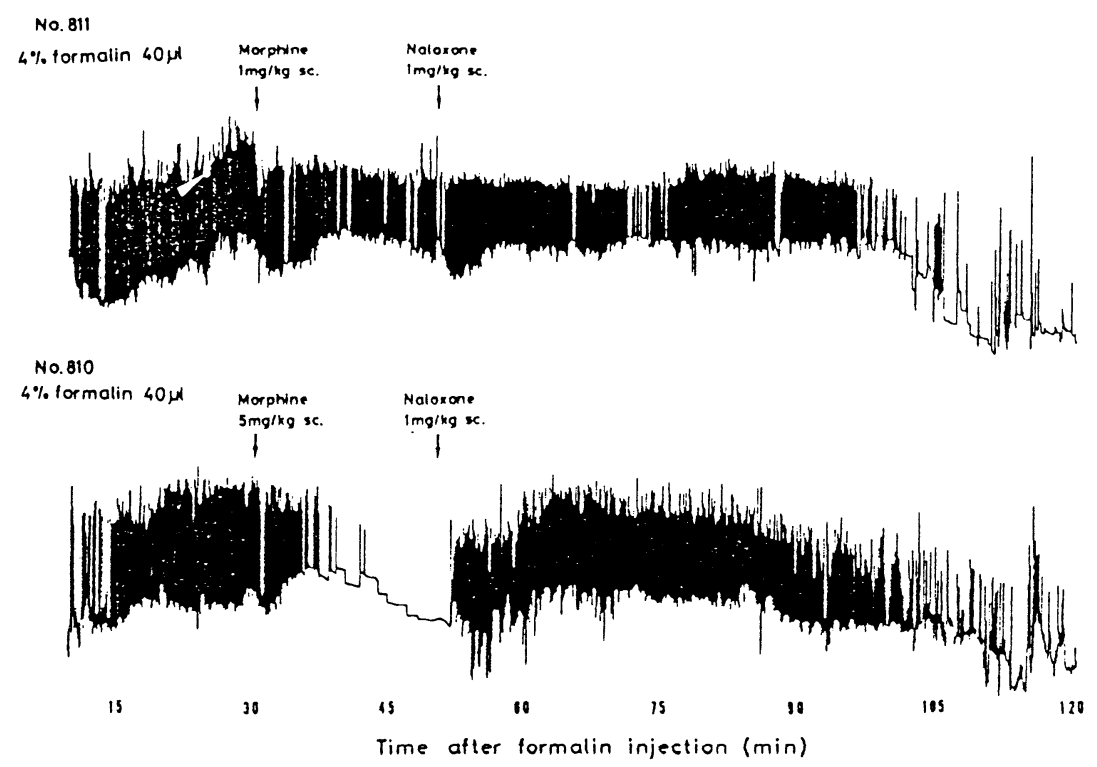

Fig. 5 Records of flexion responses by $4 \%$ formalin. These responses were inhibited moderately by $1 \mathrm{mg} / \mathrm{kg}$ of morphine (upper), and perfectly by $5 \mathrm{mg} / \mathrm{kg}$ of morphine perfectly (lower). Furthermore, these inhibitory effects of morphine were immediately antagonized by $1 \mathrm{mg} / \mathrm{kg}$ of naloxone. 
る。

最近, Dickenson \& Silluvan(1987)は，ラッ トの後肢皮下にホルマリン溶液を注入して脊 髄後角細胞の単一発射活動を記録し, 注入直後

(第 1 期) と, 20 分後から少なくとも 65 分後ま で（第 2 期）の活発なニューロン活動を報告し ている。脊髄後角細胞は, 痛覚求心路系の中継核 の一つであり，中脳や延髄などの上位中枢から 種々の制御を受け，痛みの統合に重要な役割を 果たしていることが生理学的に明らかになって いる。このような細胞の侵害受容性応答の時間 経過と，屈曲反応数のそれが極めてよく符合す るという事実は，ホルマリン誘発性後肢屈曲反 応が，少なくとも脊髄レベルでの持続性侵害受 容の行動的指標として適切であることを示唆す る。

今回の実験では，ホルマリンを注入された ラットのうち 3 匹が極端に低い反応数を示し た。これらのラットは，ナロキソン投与により 反応を一時的に回復することが確かめられた が，このことは反応抑制が単に運動障害による ものではないことを意味するとともに，そこに は内因性モルヒネ様物質が強く関与することを 示唆する。内因性モルヒ齐様物質の自発的活性 化には種々の要因が考えられるが（Rogers \& Randall 1988，山中他 1981）, 今回の実験場面で は拘束ストレスの影響がまず想定される。拘束 ストレスによる鎮痛効果の特徵の一つに，ナロ キソンによる可逆的作用が挙げられるが

(Dubuisson \& Dennis 1977)，今回の低反応 ラットもこの点は一致する。しかしながら，前 述のとおりストレス鎮痛は動物がそのストレス 状況を繰り返し経験することにより最終的に消 失するが, 本実験の低反応例は更に 12 日間の馴 化訓練を経験した後も反応数は前回と同様に極 めて少数であった。

なぜ特定のラット（約 10\%強）に低反応例が 出現するかは現時点では不明であるが，内因性 痛み抑制系，特にその自発的発現機序という点 に関して興味深い事例であり，更なる検討が必
要である。

以上，本法は，(1)痛み反応を具体的な記録と して測定するため, 判定に際し客観性および確 実性が保たれる,(2)単一反応を指標とするため, 同一の痛み成分の継時的変化が観察される，(3) ホルマリン誘発性屈曲反応は, ホルマリンによ り誘発される他の痛み反応に比べ,より長時間, 一定レベルの反応量が得られるため鎮痛効力試 験法として有用である，などの特徵をもつと考 えられる。

テストまでの馴化訓練に時間を要すること, 再現性に関して約 10\%強のラットに低反応が 出現し，しかもその原因が不明であることなど の問題点があるが，馴化訓練に関しては，測定 時間の短縮により，訓練日数も短縮することが 可能である（我々の経験では，測定時間を，高 頻度の反応が出現する 60 分間とした場合, 馴化 訓練は 4〜6 日間で充分であろう)。

近年，動物に持続的な痛みを経験させる手段 として，ホルマリン溶液の注入が広く行われる ようになった（佐藤 1986, Yaksh et al. 1979）。 痛みの程度や，その継時的変化の様相を行動的 に正しく把握することが必要であり，本法はそ のための有効な動物モデルであろうと思われ る。

\section{REFERENCES}

Abbott, F. V., Franklin, K. B. J., Ludwick, R. J. and Melzack, R. Apparent lack of torelance in the formalin test suggests different mechanisms for morphine analgesia in different types of pain. Parmacology Biochemistry \& Behavior, 1981, 15, 637 -640 .

Alreja, M., Mutalik, P. G., Nayar, U. and Manchauda, S. K. The formalin test: a tonic pain model in the primate. Pain, 1984, 20, 97-105.

Amur, S. and Amit, Z. The pituitary gland 
山崎・酒井・山中：ラットを用いた新しい持続痛測定法

mediates acute and chronic pain responsiveness in stressed and non-stressed rats. Life Sci., 1979, 24, 439-448.

De Castro-Costa, M., De Sutter, P., Gybels, J. and van Hees, J. Adjuvant induced arthritis in rats, as a possible model of chronic pain. Pain, 1981, 10, 173-186.

Dennis, G. S. and Melzack, R. Comparison of phasic and tonic pain in animals. In Bonica et al. (Eds.) Advances in Pain Research and Therapy, vol. 3. Ravan Press, 1979, 747-759.

Dickenson, R. J. and Sullivan, A. F. Subcutaneous formalin-induced activity of dorsal horn neurones in the rat: differential response to an intrathecal opiate administered pre or post formalin. Pain, 1987, 30, 349 -360 .

Dubuisson, D. D. and Dennis, G. S. The formalin test: A quantitative study of the analgesic effects of morphine, meperidine and brain stimulation in rats and cats. Pain, 1977, 4, 161-174.

Otsuki, T., Nakahama, H., Niizuma, H. and Suzuki, J. Evaluation of the analgesic effects of capsaicin using a new rat model for tonic pain. Brain Research, 1986, 365, 235-240.

Porro, C. A. and Carli, G. Immobilization and restraint effects on pain reactions in animals. Pain, 1988, 32, 289-307.

Rogeirs, R. J. and Randall, J. I. Environmentally induced analgesia: Situational factors, mechanismns and signficance. In
Rodgers and Cooper (Eds) Endorphines, Opiates and Behavioral Processes. JHON WILEY \& SONS, 1988, 107-142.

佐藤 公道 鎮痛活性の評価法.藤村・高木(編) エンケファリンとエンドルフィンー痛みの 制御をめぐって. 講談社, 1981, 204-223.

佐藤 公道 痛覚の伝達と制御に関与するぺプ チド。高木他(編)脳の生体警告系一痛みを 中心にして．東京大学出版会，1986, 203 $-221$.

Sugimoto, M., Kuraishi, Y., Satoh, M. and Takagi, H. Involvement of medullary opioid-peptidergic and spinal noradrenergic systems in the regulation of formalin -induced persistent pain. Neuropharmacology, 1986, 25, 481-485.

Wall, P. D., Devor, M., Inbal, R., Scadding, J. W., Schonfeld, D., Sertzer, Z. and Tomkiewicz, M. M. Autonomy following peripheral nerve lesions: Experimental anaesthesia dolorosa. Pain, 1979, 7, 97-105.

Willer, J. C., Boureau, F. and Berny, J. Nociceptive flexion reflexes elicted by noxious laser radiant heat in man. Pain, 1979, 7, 15-20.

Yaksh, T. L., Farb, P. H., Leeman, S. E. and Tessell, T. M. Intrathecal capsaicin depletes substance $P$ in the rat spinal cord and produces prolonged thermal analgesia. Science, 1979, 206, 481-483.

山中祥男・山崎重明・鈴木牧彦 ホルマリンテ ストによる痛みの評定. 上智大学心理学年 報，1981，6，55-67. 